\title{
Penentuan Titik Pengamatan Optimal Terhadap Kualitas Udara pada Gas Keluaran Diffuser Berbasis Internet of Things
}

\author{
Irmayatul Hikmah $^{(1, a)}$, Afifah Dwi Ramadhani ${ }^{(2, b)}$ dan Fikra Titan Syifa ${ }^{(2, c)}$ \\ (I) Teknik Biomedis, Institut Teknologi Telkom Purwokerto, Indonesia, 53147 \\ (2) Teknik Telekomunikasi, Institut Teknologi Telkom Purwokerto, Indonesia, 53147 \\ Email : ${ }^{\left({ }^{*}\right)}$ irmayatul@ittelkom-pwt.ac.id, ${ }^{(b)}$ afifahdr@ittelkom-pwt.ac.id, ${ }^{(c)}$ fikra@ittelkom-pwt.ac.id
}

Diterima (03 Maret 2021), Direvisi (22 Juli 2021)

\begin{abstract}
Indoor air quality needs attention, especially during the covid-19 pandemic because the majority of activities are carried out indoors. The air in the room must be protected from the threat of harmful virus dan bacterial contaminants. One such innovation is placing diffuser in the room. Diffuser is a device that converts liquid into gas particles in the air. To reduce harmful virus contamination, a natural antiseptic liquid is filled into the diffuser, one of which is papermint essential oil, which can provide freshness in the room. Air quality is monitored with internet of things (IoT) technology so that users can easily control air quality with just a PC/gadget. The gas output from the diffuser is detected by a gas sensor that is connected to the wemos board so that the data can be connected to the internet cloud. To obtain optimal air quality data, the placement of gas sensors in the area around the diffuser as a point of observation needs to be considered because the distribution of gas in the air is influenced by the vertical wind speed in the room, this can affect the quality of the data generated. This study aims to determine the optimal observation point on an IoT-based diffuser so that the resulting air quality data is more accurate. In this study the gas sensor was placed at a distance of 15 dan $25 \mathrm{~cm}$ from the diffuser. The direction of the gas sensor placement was adjusted according to the angle of the full circle ranging from $0^{\circ}, 45^{\circ}, 90^{\circ}, 135^{\circ}, 180^{\circ}, 225^{\circ}, 270^{\circ}, 315^{\circ}$, dan $0^{\circ}$. The distribution of gas is influenced by the vertical wind speed in the room causing the air quality data at a vertical angle to always have the same pattern. From the results obtained, the optimal observation point as a reference for the position of the gas sensor to the diffuser is at an angle between $135^{\circ}-180^{\circ}$ as well as at an angle between $315^{\circ}-0^{\circ}$.
\end{abstract}

Keywords: Air quality, diffuser, internet of things.

Abstrak. Kualitas udara di dalam ruangan perlu mendapat perhatian terutama di musim pandemi covid-19 sebab mayoritas aktivitas dilakukan di dalam ruangan. Udara dalam rungan harus dijaga dari ancaman kontaminan virus maupun bakteri berbahaya. Salah satu inovasi adalah menempatkan diffuser di dalam ruangan. Diffuser merupakan piranti yang mengubah cairan menjadi partikel gas di udara. Untuk mengurangi kontaminasi virus berbahaya, diisikan cairan antiseptik alami ke dalam diffuser yaitu salah satunya minyak ekstrak daun mint yang dapat memberi kesegaran dalam ruangan. Kualitas udara dimonitoring dengan teknologi internet of things (IoT) supaya pengguna dapat dengan mudah mengontrol kualitas udara hanya dengan PC/gadget. Gas keluaran diffuser ditangkap sensor gas yang telah terhubung dengan wemos board supaya data dapat terhubung ke cloud internet. Untuk mendapat data kualitas udara optimal, penempatan sensor gas di area sekitar diffuser sebagai titik pengamatan perlu diperhatikan sebab persebaran gas di udara dipengaruhi oleh kecepatan vertikal angin di dalam ruangan, hal ini berpengaruh terhadap kualitas data yang dihasilkan. Penelitian ini bertujuan menentukan titik pengamatan optimal pada diffuser berbasis IoT supaya data kualitas udara yang dihasilkan lebih akurat. Pada penelitian ini sensor gas ditempatkan pada jarak 15 dan $25 \mathrm{~cm}$ dari diffuser. Arah peletakan sensor gas diatur sesuai sudut pada lingkaran penuh yaitu $0^{\circ}, 45^{\circ}, 90^{\circ}$, $135^{\circ}, 180^{\circ}, 225^{\circ}, 270^{\circ}, 315^{\circ}$ dan $0^{\circ}$. Persebaran gas dipengaruhi kecepatan vertikal angin dalam ruangan menyebabkan data kualitas udara pada sudut vertikal selalu berpola sama. Dari hasil diperoleh titik pengamatan optimal sebagai acuan posisi peletakan sensor gas terhadap diffuser berada di sudut antara $135^{\circ}$ $180^{\circ}$ maupun di sudut antara $315^{\circ}-0^{\circ}$.

Kata kunci: Kualitas udara, diffuser, internet of things. 


\section{PENDAHULUAN}

Kekhawatiran akan penyebaran virus yang semakin tinggi memunculkan spekulasi bahwa virus dapat menyebar melalui udara atau airborne. Airborne disease berarti penyakit yang menyebar lewat udara atau ditularkan melalui udara. Patogen atau penyebab penyakit ini bisa dalam bentuk virus, bakteri, atau jamur. Ada beberapa kategori penyebaran airborne meliputi airborne aerosol, debu, atau cairan. [1].

Pengaruh kontaminan udara di dalam ruangan terhadap kesehatan manusia sepuluh kali lebih besar dibanding kontaminan udara di luar ruangan sebab 90\% aktivitas manusia dilakukan di dalam ruangan, terutama sejak pandemi Covid-19 [2]. Ruangan yang memiliki kualitas udara yang baik ternyata memberi dampak pada kesehatan seperti mengurangi resiko penyakit saluran pernapasan hingga meningkatkan kinerja otak. Sebaliknya ruangan yang memiliki kualitas udara yang kurang sehat akan tercemari kontaminan yang tidak terlihat secara kasat mata sehingga memudahkan penyebaran virus dan bakteri kepada penghuni yang ada di dalamnya [3].

Sebuah inovasi sistem pengontrol kualitas udara dalam ruangan adalah salah satu hal yang dibutuhkan untuk menangani pandemi COVID-19 sekaligus sebagai upaya pencegahan penyebaran virus berbahaya lain yang muncul dikemudian hari. Salah satu cara menciptakan kualitas udara yang baik dalam ruangan adalah dengan memasang perangkat elektronik seperti diffuser. Diffuser mengeluarkan uap ke udara. Uap berasal dari essential oil yang terisi di dalamnya [4]. Semburan essential oil pada diffuser yang terdiffusi dalam bentuk gas di udara dapat mengikat molekul-molekul kontaminan udara sehingga radikal bebas yang memicu pertumbuhan bakteri dan jamur berbahaya hancur [5]. Diffusi merupakan proses perpindahan oksigen dari satu fase ke fase lain biasanya dari fase cair ke fase gas, dengan semakin banyak porsi oksigen di udara membuat kualitas udara semakin baik sebaliknya porsi kontaminan semakin turun [6].

Daun mint memiliki kandungan antioksidan tinggi yang bersifat antimikroba, antitumor dan anti-alergenik sehingga cocok digunakan sebagai cairan pengisi diffuser [7]. Disamping itu aroma daun mint menambah kesegaran dalam ruangan sehingga penghuni ruangan akan merasa lebih rileks.

Internet of Things (IoT) merupakan metode yang memanfaatkan konektifitas internet untuk menghubungkan perangkat satu dengan lainnya [8]. Konsep IoT semakin banyak diterapkan pada berbagai bidang keilmuan, termasuk pada sektor medis. Pengguna dapat mengidentifikasi, memantau, dan melakukan pelacakan untuk beberapa keperluan secara otomatis dan real time [9]. Objek IoT berupa sensor memiliki rangkaian penguat operasional (op-amp) untuk mengemulsikan data berupa analog yang dapat dianalisis oleh sistem minimum. Arsitektur pada IoT didesain secara khusus untuk dapat menampung ratusan bahkan ribuan data pada berbagai kondisi dan kebutuhan [10].

Komunikasi nirkabel atau wireless communication merupakan penerapan teknologi yang memungkinkan perangkat atau device dapat saling terhubung via jaringan lokal atau WLAN. Wemos D1 adalah sebuah development board yang menggunakan teknologi $\mathrm{WiFi}$ untuk menghubungkan perangkat ke jaringan internet [11].

Platform IoT memiliki kapabilitas untuk menghubungkan beberapa perangkat ke dalam jaringan internet. Wemos D1 merupakan sistem minimum yang memiliki 
keunggulan berupa koneksi wireless berbasis mikrokontroller sehingga dapat mewujudkan konsep IoT [12].

Kemudahan dan kepraktisan dalam sistem pengontrolan kualitas udara pun memiliki peranan penting untuk membuat pengguna tidak kesulitan dalam pengaplikasian. Untuk itu diperlukan inovasi berbasis IoT pada alat diffuser sehingga pengguna dapat mengontrol kualitas udara dalam ruangan mereka secara lebih praktis dan mudah hanya dengan terhubung menggunakan internet di PC maupun smartphone [2]. IoT mengacu pada objek-objek unik yang dapat diidentifikasi dan direpresentasikan secara virtual ke dalam struktur internet [13]. Komponen yang terkoneksi ke IoT meliputi sensor gas yang dalam kondisi aktif untuk mendeteksi gas. [14]. Penempatan sensor gas di area sekitar diffuser sebagai titik pengamatan perlu diperhatikan sebab persebaran gas keluaran diffuser di udara berpola tidak beraturan yang erat hubungannya terhadap kecepatan vertikal angin di dalam ruangan. Kecepatan vertikal adalah parameter untuk mengukur suatu gerakan massa udara dalam bidang vertikal.

Pola kecepatan vertikal dianalisa menggunakan metode variogram. Variogram merupakan plot dua dimensi yang memetakan perbedaan data sebagai fungsi jarak atau posisi yang ditampilkan dalam bentuk grid-grid. Metode ini juga dapat menentukan pola distribusi spatial dan anomali. Pada variogram, nilai yang rendah akan berada di dekat nilai rendah lainnya begitu juga dengan nilai yang besar cenderung berada di dekat nilai besar lainnya. Jenis variogram ada dua yaitu isotropi dan anisotropi, isotropi hanya mempertimbangkan fungsi jarak/posisi saja sedangkan anisotropi mempertimbangkan fungsi jarak beserta arah. Pada penelitian ini dipakai variagram anisotropi yang memiliki Persamaan 1 [15]: $\gamma(h, \theta)=\left[\frac{1}{2} N(h, \theta)\right] \sum_{i=1}^{N(h, \theta)}\left[z\left(x_{i}\right)-z\left(x_{i}+h, \theta\right)\right]^{2}$ (1)

dengan $\gamma(\mathrm{h}, \theta)$ adalah variogram fungsi jarak $h$ dan arah $\theta, z\left(x_{\mathrm{i}}\right)$ adalah nilai data di titik $x_{\mathrm{i}}, z\left(x_{\mathrm{i}}+h, \theta\right)$ adalah nilai data di titik $x_{\mathrm{i}}$ $+h, \theta, N(h, \theta)$ adalah banyak pasangan titik. Penentuan titik pengamatan yang optimal pada diffuser berbasis IoT ini penting dilakukan supaya data kualitas udara yang dihasilkan akurat.

\section{METODE PENELITIAN}

Penelitian dilakukan secara indoor dengan menempatkan diffuser yang berisikan air yang sudah diteteskan papermint essential oil dalam suatu ruangan tertutup. Sensor gas ditempatkan pada jarak $15 \mathrm{~cm}$ maupun $25 \mathrm{~cm}$ terhadap diffuser. Peletakan sensor gas ini memperhatikan sudut pada lingkaran penuh dengan penggantian posisi sensor gas tiap kenaikan sudut $45^{\circ}$ seperti yang ditunjukkan pada

\section{Gambar 1:}

Sensor gas yang digunakan pada eksperimen adalah MQ 135 yang terhubung ke Wemos D1 seperti Gambar 2. Wemos D1 terhubung ke jaringan internet secara otomotis untuk mentransmisikan data dari sensor MQ 135. Parameter data dari sensor

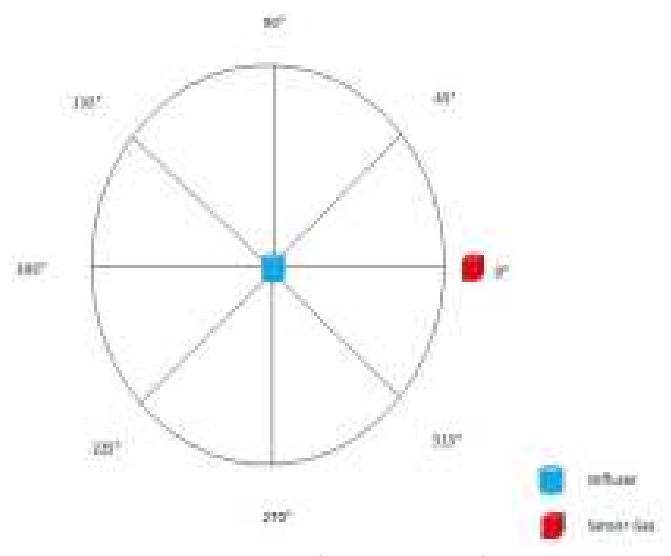

Gambar 1. Skema Percobaan

MQ 135 dikirim melalui platform Thingspeak. Data yang didapatkan 
disimpan dalam Thingspeak cloud dengan mengirimkan data setiap 20 detik sekali. Sistem monitoring bekerja dengan membaca sensor MQ135 yang terhubung dengan Wemos D1 untuk mengambil data kualitas udara berupa data ADC dan diteruskan ke Thingspeak cloud dengan menggunakan koneksi Wi-Fi. Di dalam Thingspeak, data diolah menjadi sebuah grafik yang ditampilkan dalam monitor PC/gadget. Data-data tersebut selanjutnya akan dianalisa dan dikategorikan sesuai indikator kualitas udara seperti yang ditunjukkan pada Tabel 1 [14]. Gambar 3 menunjukkan blok diagram dari penelitian.

Pengambilan data pertama dilakukan pada jarak sensor gas-diffuser sebesar 15 $\mathrm{cm}$. Sensor gas diletakkan urut sesuai sudut pada lingkaran penuh yaitu $0^{\circ}, 45^{\circ}, 90^{\circ}$, $135^{\circ}, 180^{\circ}, 225^{\circ}, 270^{\circ}, 315^{\circ}$ dan kembali ke keadaan awal $0^{\circ}$. Diambil data kualitas udara pada tiap sudut percobaan masingmasing selama 15 menit. Pengambilan data kedua dilakukan pada jarak sensor gasdiffuser sebesar $25 \mathrm{~cm}$. Sensor gas juga diletakkan urut sesuai sudut yaitu $0^{\circ}, 45^{\circ}$, $90^{\circ}, 135^{\circ}, 180^{\circ}, 225^{\circ}, 270^{\circ}, 315^{\circ}$ dan $0^{\circ}$. Waktu yang dibutuhkan tiap sudut percobaan juga selama 15 menit.

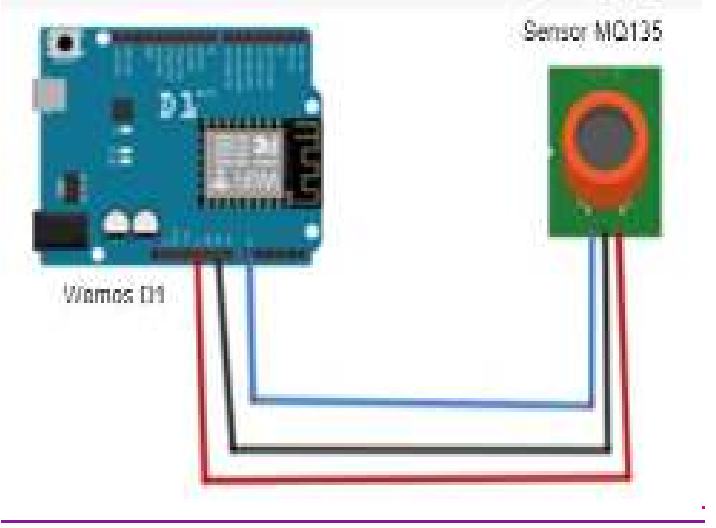

Gambar 2. Skema Desain
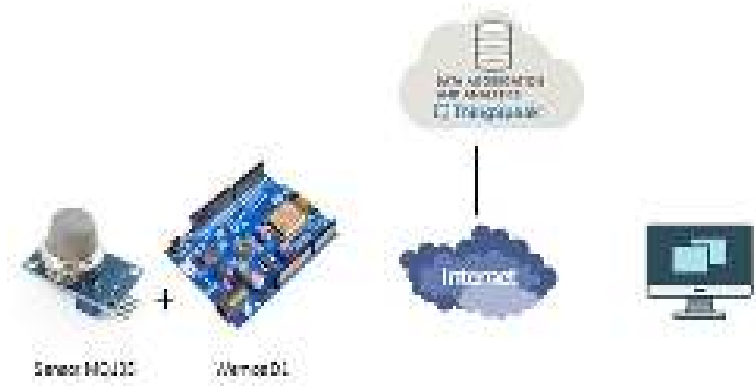

Gambar 3. Blok Diagram

Tabel 1. Level kualitas udara

\begin{tabular}{cc}
$\begin{array}{c}\text { Level air } \\
\text { quality }\end{array}$ & Kategori \\
\hline$>\mathbf{8 0 0}$ & Tinggi polusi \\
$\mathbf{4 0 0 - 8 0 0}$ & Rendah polusi \\
$<\mathbf{4 0 0}$ & Udara Normal \\
\hline
\end{tabular}

\section{HASIL DAN PEMBAHASAN}

Dari pengambilan data baik itu pertama maupun kedua diperoleh rata-rata kualitas udara yang ditunjukkan pada Tabel 2. Jika divisualisasikan sesuai urutan sudut saat percobaan dalam bentuk gambar, dapat dilihat pada Gambar 4 dan Gambar 5. Untuk mengetahui persebaran gas dengan metode variogram, dibuat citra dua dimensi dengan bantuan program matlab dimana level warna menunjukan kualitas udara yang diperoleh seperti yang ditunjukkan pada Gambar 6 dan Gambar 7.

Tabel 2. Rata-rata kualitas udara yang diperoleh

\begin{tabular}{ccrr}
\hline No & $\begin{array}{c}\text { Sudut } \\
(\mathbf{(})\end{array}$ & \multicolumn{2}{c}{ Kualitas Udara } \\
& & $\begin{array}{c}\text { Jarak 15 } \\
\text { cm }\end{array}$ & $\begin{array}{c}\text { Jarak 25 } \\
\text { cm }\end{array}$ \\
\hline 1 & 0 & 63.06 & 170.73 \\
2 & 45 & 65.05 & 53.02 \\
3 & 90 & 67.69 & 52.98 \\
4 & 135 & 170.62 & 51.93 \\
5 & 180 & 51.66 & 143.58 \\
6 & 225 & 60.02 & 47.35 \\
7 & 270 & 99.21 & 49.55 \\
8 & 315 & 106.91 & 50.78 \\
9 & 0 & 63.06 & 170.73 \\
\hline
\end{tabular}




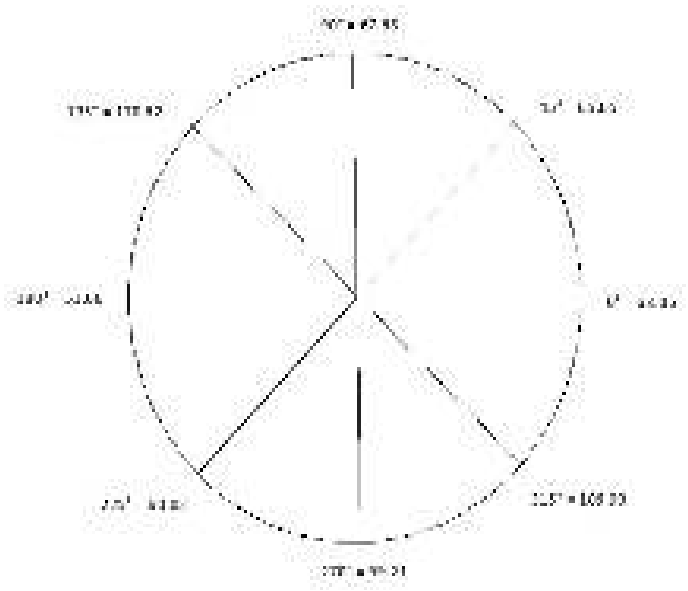

Gambar 4. Hasil pengambilan data jarak $15 \mathrm{~cm}$

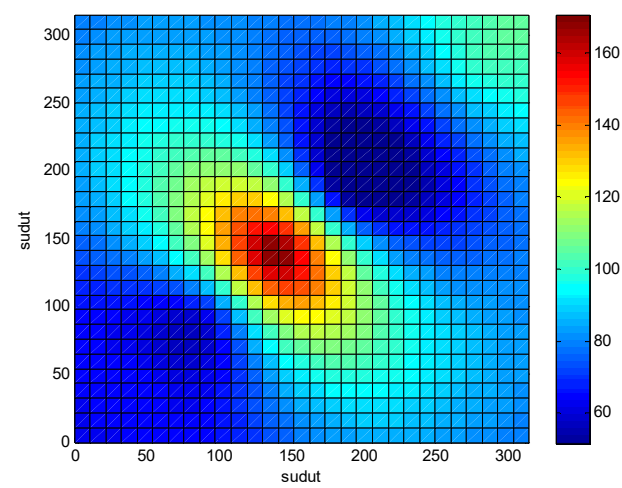

Gambar 6. Variogram persebaran gas pada jarak $15 \mathrm{~cm}$

Jika diperhatikan dengan seksama, kecepatan vertikal angin mempengaruhi kualitas udara yang ditangkap oleh sensor gas. Dari hasil pengambilan data pertama (Gambar 4) yaitu pada jarak diffusersensor gas sebesar $15 \mathrm{~cm}$, angka kualitas udara mulai dari sudut $0^{\circ}, 45^{\circ}, 90^{\circ}, 135^{\circ}$ sebesar 63.06, 65.05, 67.69, 170.62 sedangkan untuk sudut berikutnya yaitu $180^{\circ}, 225^{\circ}, 270^{\circ}$, dan $315^{\circ}$ angka kualitas udara lansung turun dari semula tertinggi 170.62 menjadi $51.66,60.02$, 99.21, dan 106.91. Disini teramati pola kecepatan vertikal angin yaitu angka kualitas udara pada sudut $0^{\circ}$ linear atau berbdaning lurus dengan angka kualitas udara pada sudut $180^{\circ}$ yaitu nilai terendah sedangkan nilai

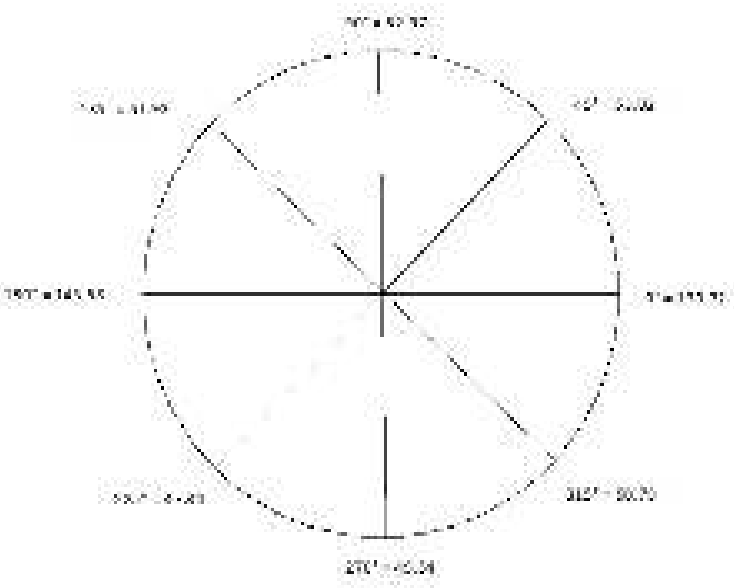

Gambar 5. Hasil pengambilan data jarak $25 \mathrm{~cm}$

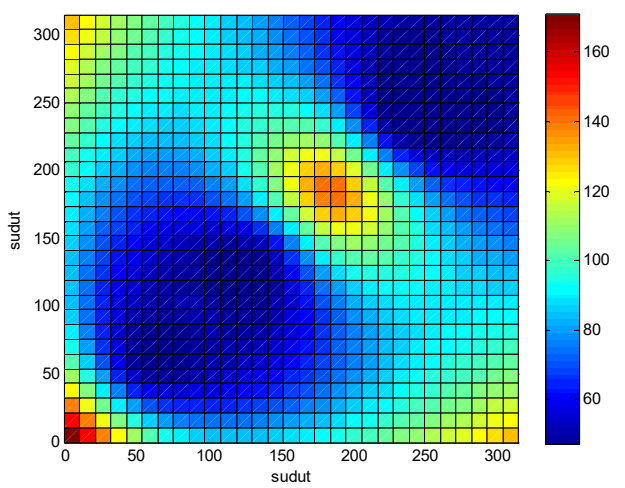

Gambar 7. Variogram persebaran gas pada jarak $25 \mathrm{~cm}$

tertinggi yaitu angka kualitas udara pada sudut $135^{\circ}$ linear atau berbdaning lurus dengan angka kualitas udara pada sudut $315^{\circ}$. Untuk sudut-sudut vertikal yang lain pun, pola kualitas udara yang dihasilkan sama yaitu $45^{\circ}$ dengan $225^{\circ}$ dan $90^{\circ}$ dengan $270^{\circ}$ bersesuaian pola urutan dari terendah sampai tertinggi.

Dari hasil pengambilan data kedua (Gambar 5) yaitu pada jarak diffusersensor gas sebesar $25 \mathrm{~cm}$, angka kualitas udara mulai dari sudut $0^{\circ}, 45^{\circ}, 90^{\circ}, 135^{\circ}$ sebesar 170.73, 53.02, 52.98, 51.93 sedangkan untuk sudut berikutnya yaitu $180^{\circ}, 225^{\circ}, 270^{\circ}$, dan $315^{\circ}$ angka kualitas udara lansung naik dari semula terendah 51.93 menjadi $143.58,47.35,49.55$, dan 
50.78. Disini juga teramati pola kecepatan vertikal angin yaitu angka kualitas udara pada sudut $0^{\circ}$ linear atau berbdaning lurus dengan angka kualitas udara pada sudut $180^{\circ}$ yaitu nilai tertinggi sedangkan nilai terendah yaitu angka kualitas udara pada sudut $135^{\circ}$ linear atau berbdaning lurus dengan angka kualitas udara pada sudut $315^{\circ}$. Untuk sudut-sudut vertikal yang lain pun, pola kualitas udara yang dihasilkan sama yaitu $45^{\circ}$ dengan $225^{\circ}$ dan $90^{\circ}$ dengan $270^{\circ}$ bersesuaian pola urutan dari tertinggi sampai terendah.

Dari kedua pengambilan data ini diperoleh pola kualitas udara akan semakin naik atau semakin turun tiap kenaikan empat tingkatan sudut mulai dari $0^{\circ}$ sampai $135^{\circ}$ maupun $180^{\circ}$ sampai $315^{\circ}$. Hal ini menunjukan pola persebaran gas keluaran diffuser bersesuaian dengan kecepatan vertikal angin dalam ruangan. Pergerakan angin secara vertikal mempengaruhi penyebaran gas keluaran diffuser.

Variogram yang terbentuk pada Gambar 6 dan Gambar 7 menunjukkan titik pengamatan optimal terjadi pada posisi anomali berwarna merah kekuningan sedangkan pada daerah berwarna biru bukan titik pengamatan yang disarankan sebab data cenderung homogen. Pada jarak $15 \mathrm{~cm}$ titik pengamatan optimal terjadi pada sudut $135^{\circ}$ yang vertikal dengan sudut $315^{\circ}$ sedangkan pada jarak $25 \mathrm{~cm}$ titik pengamatan optimal terjadi pada sudut $180^{\circ}$ yang vertikal dengan sudut $0^{\circ}$. Dari keduanya ditarik kesimpulan bahwa titik pengamatan optimal sebagai acuan posisi peletakan sensor gas terhadap diffuser berada di sudut antara $135^{\circ}-180^{\circ}$ ataupun di sudut antara $315^{\circ}-0^{\circ}$ sebab adanya kecepatan angin vertikal. Pada posisi tersebut data yang diperoleh cenderung lebih bervariasi atau inhomogen.

Semakin rendah angka kualitas udara semakin banyak kdanungan oksigen dalam ruangan yang menyebabkan ruangan semakin sehat sebaliknya semakin tinggi angka kualitas udara semakin sedikit kdanungan oksigen dalam ruangan. Apabila angka kualitas udara semakin naik (kdanungan oksigen semakin turun) pengguna dapat menambahkan tetesan papermint essential oil ke dalam diffuser yang hanya dapat diketahui melalui monitoring grafik kualitas udara pada www.thingspeak.com melalui $\mathrm{PC} /$ gadget.

\section{KESIMPULAN}

Pergerakan angin secara vertikal dalam ruangan mempengaruhi persebaran gas keluaran diffuser di udara sehingga data kualitas udara disetiap titik pengamatan akan berbeda bergantung posisi peletakan sensor gas terhadap diffuser. Data kualitas udara pada sudut vertikal selalu berpola sama yang dipengaruhi kecepatan angin vertikal. Dari hasil analisa diperoleh titik pengamatan optimal sebagai acuan posisi peletakan sensor gas terhadap diffuser berada di sudut antara $135^{\circ}-180^{\circ}$ maupun di sudut antara $315^{\circ}-0^{\circ}$.

\section{UCAPAN TERIMAKASIH}

Penulis mengucapkan terimakasih kepada Lembaga Penelitian dan Pengabdian Masyarakat Institut Teknologi Telkom Purwokerto yang telah memberikan dana hibah penelitian melalui skema pendanaan penelitian internal sehingga penulis dapat menyelesaikan penelitian ini dengan baik.

\section{DAFTAR PUSTAKA}

[1] Y. Shen, C. Li, dan H. Dong, "Airborne Transmission of Covid-19: Epidemiologic Evidence From Two Outbreak Investigations," Ssrn Electron. J., Jan. 2020, Doi: 10.2139/Ssrn.3567505.

[2] F. Pradityo dan N. Surantha, "Indoor Air Quality Monitoring dan Controlling System Based On Iot dan Fuzzy Logic," In 2019 7th International 
Conference On Information dan Communication Technology (Icoict), Jul. 2019, Pp. 1-6, Doi: 10.1109/Icoict.2019.8835246.

[3] B. W. Dionova, M. N. Mohammed, S. Al-Zubaidi, dan E. Yusuf, "Environment Indoor Air Quality Assessment Using Fuzzy Inference System," Ict Express, Vol. 6, No. 3, Pp. 185-194, Sep. 2020, Doi: 10.1016/J.Icte.2020.05.007.

[4] D. N. S. Dewi, "Aktivitas Antibakteri Minyak Atsiri Batang Sereh (Cymbopogon Citratus) Terhadap Propionibacterium Acnes Secara In Vitro," Feb. 2016, Accessed: Apr. 29, 2020. [Online]. Available: Http://Repository.Unej.Ac.Id/Hdanle/1 $23456789 / 73586$.

[5] H. Edi, A. A. Irene, dan S. Retno Susetyaningsih, "Pengaruh Bentuk Difuser Terhadap Transfer Oksigen," J. Rekayasa Perenc., Vol. 2, No. 1, Oct. 2005, Accessed: Apr. 29, 2020. [Online]. Available: Http://Eprints.Upnjatim.Ac.Id/2544/.

[6] E. Suryadi, "Transfer Oksigen Dalam Proses Aerasi," J. Kim. dan Kemasan, Vol. 0, No. 0, Pp. 24-30, Feb. 2009, Doi: $10.24817 /$ Jkk.V0i0.4731.

[7] M. G. Figueroa Pérez, N. E. RochaGuzmán, E. Mercado-Silva, G. LoarcaPiña, dan R. Reynoso-Camacho, "Effect Of Chemical Elicitors On Peppermint (Mentha Piperita) Plants dan Their Impact On The Metabolite Profile Dan Antioxidant Capacity Of Resulting Infusions," Food Chem., Vol. 156, Pp. 273-278, Aug. 2014, Doi: 10.1016/J.Foodchem.2014.01.101.

[8] "Implementasi Konsep Internet Of Things Pada Sistem Monitoring Banjir Menggunakan Protokol MQTT | Jurnal Pengembangan Teknologi Informasi dan Ilmu Komputer," Accessed: Mar. 16, 2021. [Online]. Available: Http://J-
Ptiik.Ub.Ac.Id/Index.Php/J-

Ptiik/Article/View/3529.

[9] A. Junaidi, "Internet Of Things, Sejarah, Teknologi dan Penerapannya: Review," J. Ilm. Teknol. Inf. Terap., Vol. I, Pp. 62-66, Aug. 2015.

[10] M. Bhayani, M. Patel, dan C. Bhatt, "Internet Of Things (Iot): In A Way Of Smart World," Vol. 438, 2016, Pp. 343-350.

[11] N. Cameron, Arduino Applied: Comprehensive Projects For Everyday Electronics. 2019.

[12] M. Fauzan, M. Muhaimin, dan A. Finawan, "Telemetri Suhu Multi Node Berbasis Internet of Things Menggunakan Modul Wemos D1r2," J. Tektro, Vol. 1, No. 1, Art. No. 1, Sep. 2017.

[13] C.-T. Yang, S.-T. Chen, W. Den, Y.-T. Wang, dan E. Kristiani, "Implementation Of An Intelligent Indoor Environmental Monitoring dan Management System In Cloud," Future Gener. Comput. Syst., Vol. 96, Pp. 731749, Jul. 2019, Doi: 10.1016/J.Future.2018.02.041.

[14] J. M. S. Waworundeng dan O. Lengkong, "Sistem Monitoring dan Notifikasi Kualitas Udara Dalam Ruangan Dengan Platform Iot," Cogito Smart J., Vol. 4, No. 1, Pp. 94-103, Jun. 2018, Doi: 10.31154/Cogito.V4i1.105.94-103.

[15] M. Ramadhan, A. Putri, A. Kurniawan, dan A. Irawan, "Prioritas Arah Penempatan Titik Pengamatan Kecepatan Vertikal Di Kalimantan Menggunakan Analisis Anisotropi," $J$. Meteorol. Klimatol. Dan Geofis., Vol. 5, Pp. 63-71, Apr. 2019, Doi: 10.36754/Jmkg.V5i3.76. 
Irmayatul Hikmah, dkk.: Penentuan Titik Pengamatan Optimal Terhadap Kualitas Udara pada Gas Keluaran Diffuser Berbasis Internet of Things 